\title{
Public Schools and the Pattern of Intraurban Residential Mobility
}

\section{G. Donald Jud and D. Gordon Bennett}

Thirty years ago, Charles Tiebout (1956) recognized that households consider differences in the benefits and costs of public services in choosing where to live. Following Wallace Oates's (1969) path-breaking article, a number of studies confirmed that the price of residential real estate was influenced by the quality of local public services and the local tax rate.

Studies of housing value, however, relate only indirectly to the intraurban movement of population that is central to the Tiebout model. Much less is known about the pattern of intraurban mobility and how this pattern is influenced by the availability and quality of public goods, such as schools.

Indeed, most of the research on the behavioristic, micro-scale level can be traced to the works of Rossi (1955) and Hagerstrand (1962), both of which emphasize the overriding importance of life-cycle changes in stimulating residential mobility. Wolpert (1965) states that individuals (and households are continually comparing-even if subconsciously - the "net composite of utilities" of the place they live with those of all other places with which they are familiar. The perceived differential utility is a function of the various changes occurring near the present residence and of the changing aspirations and household relationships through time. Brown and Moore (1970) believe that the criteria used in deciding on a new residence depends on a household's aspiration level, which they define as (1) the relative importance of certain variables to the household, (2) the perception of the household in obtaining a desired residence, and (3) the financial possibility of se-

\footnotetext{
Land Economics Vol. 62, No, 4, Nov, 1986 0023-7639/86/001-0001 \$1.50/0 C) 1986 by the Board of Regents of the University of Wisconsin System
}

curing it. (Reviews of migration literature include those by Bennett and Gade [1979], Brown [1977], de Castro Lopo [1975], Greenwood [1975], and Willis [1974].)

The focus of this study is on the impact of public schools on the pattern on intraurban migration. When ranked in terms of expenditures, public schooling is the most important public service provided by local governments. In 1980, 44 percent of all local government expenditures were for educational purposes.

The importance of public schools as a factor in household location choice is suggested by a number of national opinion polls. Eightynine percent of those interviewed in a 1976 Harris survey reported that the achievement of quality education for children was very important to the quality of American life (Harris 1976). Those polled in this survey ranked quality education as the nation's number-one quality-of-life issue. In 1983, 58 percent of respondents in a nationwide Gallup Poll reported that they would be willing to pay higher taxes to help raise the nation's quality of education (Gallup 1983).

A 1976 Harris survey conducted for the U. S. Department of Housing and Urban Development questioned 7,074 households across the country on the importance of various factors affecting their choice of location. For those with school-age children, public schools were the most important factor affecting their choice of where to live. For this group, schools ranked as more important than convenience of location, affordability, housing characteristics, and neighborhood safety. Among all homeowners, 32 percent reported that schools were very important in their choice of residence. Ranked on this basis, public schools were the fourth most important

\footnotetext{
University of North Carolina, Greensboro.
} 
factor affecting homeowner location (Jud 1985).

The dimension of public schooling that has received the most attention as a factor influencing household location is the racial mix of the student population. Interest in this topic was stimulated greatly by James Coleman's (1975) study which concluded that school desegregation had contributed to the substantial movement of whites away from central cities, that is, what has been termed "white flight." Although initially Coleman's work was widely disputed, subsequent research by Reynolds Farley and Clarence Wurdock (1977), Christine Rossell (1978a), and Charles Clotfelter (1979) offered conclusions very similar to the original Coleman study.

The most common explanation for the white flight documented by Coleman and others involves racist attitudes on the part of white parents. That is, many believe that white parents have chosen to withdraw their children from desegregated schools simply because they do not want to send them to school with blacks.

There are several problems, however, with such a strictly racist interpretation of the flight from inner-city public schools. One is that it does not explain why large numbers of urban blacks also have withdrawn their children from public schools, many enrolling in private religious schools. (See, Williams 1981.)

A strictly racist interpretation also does not agree with the results of public opinion polls. A 1976 Harris poll showed that only 38 percent of blacks and 9 percent of whites favored "busing school children to achieve racial balance" (Rossell 1978b, 51). In Boston, a poll conducted by the Boston Globe in 1982 found that 79 percent of black parents favored freedom of choice rather than mandatory court assignment to insure racial balance (Chang 1983, 3).

Evidence of the success of magnet schools in such widely diverse cities as Dallas, Detroit, Houston, and Montclair, New Jersey, further suggests that white flight may not be solely racially motivated (Christian Science Monitor 1982). In these cities, magnet schools situated in minority neighborhoods (sometimes in badly deteriorating isolated black schools) have attracted large numbers of white parents who are willing to enroll their children in schools in black neighborhoods with black children when they are convinced that the magnet schools provide superior education.

Separate studies of housing values in Charlotte (Jud and Watts 1981) and Dallas (Vandell and Zerbst 1984) have shown that the academic quality of public schools has a strong, significant influence on housing values that is independent of the racial composition of the schools. These studies suggest that the influence of school quality on housing demand cannot be explained simply as a race-related reaction to efforts designed to achieve school integration.

This paper examines the influence of school quality and student racial composition in shaping the pattern of intraurban migration. The first section develops a model of intraurban migration. The second section tests the model using data from a survey of recent homebuyers in Charlotte, North Carolina. In the third section, the model is re-estimated using data on school enrollment changes in Los Angeles County, California. The final section summarizes relevant findings. In both Charlotte and Los Angeles, the academic quality of public schools is found to be a significant factor in shaping the pattern of intraurban mobility, and this effect appears to be independent of school racial composition.

\section{A MODEL OF INTRAURBAN MIGRATION}

The basic hypothesis of this paper is that decision-making units, usually households, relocate in urban areas in response to specified incentives and that the quality of public education, independent of school racial composition, is important in shaping the pattern of intraurban migration. Incentive effects derive from the influence of intraurban differences in neighborhood amenities, public goods (including schools), proximity to employment, quality of housing and other factors on household utility functions.

The probability that a household will move from neighborhood $j$ to neighborhood $i$ is a function of the utility levels and the cost of residences in the two neighborhoods and the cost of moving. 
The cost of moving from one neighborhood to another in an urban area can be reasonably assumed to be constant, since the cost of transport over a limited distance is relatively small compared to the fixed costs of loading and unloading. Thus, the expected number of inmigrants $(I)$ from neighborhood $j$ to neighborhood $i$ is assumed to be

$$
\begin{aligned}
I_{i j}(t)= & f\left[A_{i}(t), A_{j}(t), S_{i}(t), S_{j}(t), D_{i}(t), D_{j}(t), H_{j}(t),\right. \\
& \left.C_{i}(t), C_{j}(t), P_{i}(t), P_{j}(t)\right] \\
& \text { for } j=1, \ldots n
\end{aligned}
$$

where,

$$
\begin{aligned}
A_{i}(t)= & \text { a vector of neighborhood amenities } \\
& \text { in neighborhood } i, \\
S_{i}(t)= & \text { a vector of public services in neigh- } \\
& \text { borhood } i, \\
D_{i}(t)= & \text { distance to employment from } \\
& \text { neighborhood } i, \\
H_{i}(t)= & \text { housing quality in neighborhood } i, \\
& \text { and } \\
C_{i}(t)= & \text { cost of residence in neighborhood } \\
& i .
\end{aligned}
$$

Total net migration for neighborhood $i$ is estimated as

$$
\begin{aligned}
\operatorname{NET}_{i}(t)= & f\left[A_{i}(t), S_{i}(t), D_{i}(t), H_{i}(t),\right. \\
& \left.C_{i}(t), P_{i}(t)\right], i=1, \ldots n .
\end{aligned}
$$

The rate of net-migration is obtained by dividing $N E T_{i}(t)$ by the population of neighborhood $i$. And the net-migration rate is given by

$$
\begin{aligned}
\operatorname{NMR}_{i}(t)= & f\left[A_{i}(t), S_{i}(t), D_{i}(t), H_{i}(t),\right. \\
& \left.C_{i}(t)\right], i=1, \ldots n .
\end{aligned}
$$

\section{INTRAURBAN MOBILITY PATTERNS IN CHARLOTTE}

Data to estimate equation [1] were obtained from a survey of 1,176 households in the city of Charlotte, North Carolina, who purchased homes in 1977. The city of Charlotte is the principal city in Mecklenburg County. A single, consolidated public school system serves all of Mecklenburg County. The Charlotte public schools have been under courtordered desegregation since the 1970-71 school year. The pairing or clustering of elementary schools from different sections of the city has been a principal tool of school desegregation employed by the district court. Prior to 1977, school assignment zones had been stable for almost three years.

The homebuyer survey was restricted to the city of Charlotte in order to make it relatively homogeneous with regard to tax rates and the availability of major public services such as water and sewer. The sample was drawn from the 1978 Master Appraisal File obtained from the Tax Supervisor of Mecklenburg County. The 1978 Appraisal File listed 3,418 singlefamily residential properties sold in 1977. From this list, a check of the City Directory and other sources revealed that 2,290 of the buyers who bought homes in 1977 were still living in the same home during the summer of 1981. Some homebuyers had moved, while others had never lived on the property, having instead purchased it for investment purposes. Mail questionnaires were sent to each of these 2,290 households and follow-ups of nonrespondents also were made by mail. Usable responses were obtained from 1,176 households - an overall response rate of 51 percent. Black households represented 9.8 percent of the usable responses.

All respondents to the survey were asked to list their prior address. Out of the 1,176 households who responded to the survey, 814 previously had lived in Charlotte before moving to their present address. The remaining inter-city movers were dropped from the analysis so that the sample contained only intracity movers. A check of the School Locator Directory revealed that out of the 54 elementary school pairings or clusters within the city of Charlotte in 1977, survey buyers had purchased homes in 50 of the 54 elementary attendance areas.

Using these data, equation [1] was estimated as follows: 


$$
\begin{aligned}
M_{i j}= & a_{0}+b_{1} Q_{i}+b_{2} Q_{j}+b_{3}\left(Q_{i} / Q_{j}\right)+ \\
& b_{4} R_{i}+b_{5} R_{j}+b_{6}\left(R_{i} / R_{j}\right)+b_{7} Y_{i}+ \\
& b_{8} Y_{j}+b_{9}\left(Y_{i} / Y_{j}\right)+b_{10} B_{i}+ \\
& b_{11} B_{j}+b_{12}\left(B_{i} / B_{j}\right)+b_{13} D_{i}+ \\
& b_{14} D_{j}+b_{15}\left(D_{i} / D_{j}\right)+b_{16} A_{i}+ \\
& b_{17} A_{j}+b_{18}\left(A_{i} / A_{j}\right)+b_{19} P_{i}+ \\
& b_{20} P_{j}+e_{i j}
\end{aligned}
$$

where,

$M_{i j}=$ the number of in-migrant homebuyers moving from school attendance area $j$ into school attendance area $i$;

$Q_{i}=$ average third-grade reading score in the neighborhood school attendance area in 1977 on the North Carolina test of student achievement;

$R_{i}=$ percent of non-white students in the neighborhood elementary school attendance area;

$Y_{i}=$ average family income (1970) in the census tract(s) served by the school attendance area (in $\$ 1,000$ s);

$B_{i}=$ average percentage of black residents in the census tract(s) served by the school attendance area;

$D_{i}=$ the average number of miles from the center of the census tract(s) served by the school cluster to the major employment centers of the Charlotte SMSA;

$A_{i}=$ the average age of the owneroccupied housing bought in 1977 in the school attendance area;

$P_{i}=$ the estimated population of the school attendance area (in 1,000's), and;

$e_{i j}=$ random error term.

The elementary school pairing or cluster formed the basic unit of analysis. Since there were 50 elementary attendance areas listed as location choices by intraurban movers, the sample provided 2,500 observations on the dependent variable $M_{i j}$.

The varibles $Q_{i}$ and $R_{i}$ were used as measures of the character of public education in the elementary school cluster. Both of these variables have received attention as determinants of residential location. Hedonic studies of housing values (Harrison and Rubinfeld [1978] and Li and Brown [1980]) normally have used measures of student achievement or school inputs (such as expenditures per pupil) as proxies for the quality of education. The importance of the racial composition of public schools has been stressed in research by James Coleman (1975). As discussed above, Coleman's work suggests that whites tend to move away from districts where the concentration of non-white pupils is high.

Our use of test scores as an index of school quality is dictated by our belief that rightly or wrongly, most parents view school-wide performance scores as a rough index of educational quality. Two decades ago, with the release of James Coleman's (1966) study, Equality of Educational Opportunity, it became popular to believe that educational quality was determined by the socioeconomic class and race of students and had little to do with the level of input or resources expended in the educational process. New research, however, offered a different view. Stewart Purkey and Marshall Smith (1982) examined more than 40 studies of the factors most important to good schooling. They found that the consensus of these studies was that some schools were better than others because some teachers and administrators were simply more effective. In a study of reading achievement levels of children in low-income neighborhoods in Los Angeles, David Armor (1976) reported that achievement levels were strongly influenced by school policies and classroom settings. Similar conclusions were reported in studies of schools in Chicago and Brooklyn (Levine and Stark 1982) and in London (Rutter 1979). Taken together, these studies suggest that school quality and achievement levels differ across urban neighborhoods and that these differences many times are independent of race and socioeconomic class.

The model includes measures of the racial composition $\left(B_{i}\right)$ and the average family income $\left(Y_{i}\right)$ of neighborhood residents. Both of these variables are proxies for amenities of the neighborhood, such as, the quality of parks and playgrounds, maintenance of lawns and streets, etc., as well as the quality of neighborhood housing. The income variable serves an additional function as a measure for the cost of housing services in the neighborhood.

The racial variable $\left(B_{i}\right)$ also captures pref- 
erence for segregated housing. Differences in the number of children per household between black and white families and in the fraction of children enrolled in private schools as well as the intra-district busing of children for desegregation mean that the racial composition of the assigned public schools cluster $\left(R_{i}\right)$ will be different from the racial mix of the neighborhood $\left(B_{i}\right)$. Accordingly, while the coefficients of both these variables may be negative, their effects may be quite different. For instance, childless couples and singles might be quite unconcerned about the racial composition of the schools but very much influenced by the racial make-up of the neighborhood.

The age variable $\left(A_{i}\right)$ was included as an additional measure of the quality of housing and other services available in the neighborhood.

The population of the neighborhood $\left(P_{i}\right)$ was used as a control for neighborhood size.

The measures of neighborhood income and racial composition were constructed from census sources (1970). Census tracts were overlaid onto the school assignment zones, and average income and neighborhood racial mix were calculated for each of the 50 school clusters.

The distance variable $\left(D_{i}\right)$ was constructed in a similar way. First, the average distance from the center of each census tract to the largest employment centers of the Charlotte area was determined by using 1970 data on employment by place of work obtained from the Charlotte Planning Department. Second, a weighted average distance for each tract was calculated using total employment weights. Finally, tracts were overlaid onto school clusters and an average distance from each cluster to employment centers was determined, using the total number of housing sales within a tract to determine its weight in the cluster average.

The measures of neighborhood age and population $\left(A_{i}\right.$ and $\left.P_{i}\right)$ were estimated from data provided by the Tax Supervisor of Mecklenburg County and the Charlotte-Mecklenburg Public Schools.

The ratio variables included in equation [4] express the status of the household's new neighborhood relative to its old neighborhood. The concept of minimal displacement first employed by Homer Hoyt (1939) in his sector theory of urban development suggests that most intraurban movers are not likely to make dramatic changes in the character of the neighborhood in which they live. Families in the poorest areas of the city are not likely to purchase homes in the city's richest neighborhoods when they move. Similarly, families living in the worst school areas are not likely to move to the best attendance areas in a single move. Instead, most movers are likely to make only modest changes in the character of their neighborhoods. This is because the likelihood of finding a vacancy to match the aspiration criteria of the household is influenced by its spatial perception and knowledge of the city. This information depends on the awareness space, vacancies, the sources used and the facility of the household in housing search. The coefficients on all of the ratio variables are expected to be negative. No ratio was included for population.

The estimated coefficients of the migration model are shown in Table 1. All of the coefficients on the ratio variables have the expected negative signs, except the one for age.

Urban movers are influenced significantly in their choice of neighborhood by the quality of public education. The estimated coefficients shown in Table 1 indicate that households are likely to move out of neighborhoods where school quality is low and into neighborhoods where it is high.

These findings support the housing price effects reported by Jud and Watts (1981) and Vandell and Zerbst (1984). In interpreting these results, it is useful to remember that this model of neighborhood choice reflects the workings of both demand and supply forces in the urban real estate market. Desirable neighborhood amenities, such as good public schools, usually result in higher housing prices as households compete for housing in the area. Higher housing prices dampen the incentive of some consumers to move to an area, but at the same time, higher prices normally will bring forth an increase in the quantity of housing supplied, except in those cases where zoning ordinances or the physical shortage of land prevent it. Additional supply, therefore, usually will be available, albeit at somewhat higher prices. The neighborhood choice model shown in Table 1 indicates that 
TABLE 1

INTRA-URBAN NEIGHBORHOOD IN-MigRATION IN ChaRLotTE, 1977

$(\mathrm{N}=2500)$

\begin{tabular}{|c|c|c|c|c|}
\hline \multirow[b]{2}{*}{ Variable } & \multicolumn{2}{|c|}{ (I) } & \multicolumn{2}{|c|}{ (II) } \\
\hline & $\begin{array}{l}\text { Coefficient } \\
\text { (Beta) }\end{array}$ & $t$-value & $\begin{array}{l}\text { Coefficient } \\
\text { (Beta) }\end{array}$ & $\mathrm{t}$-value \\
\hline Constant & 7.057 & 3.90 & 3.54 & 2.34 \\
\hline \multicolumn{5}{|c|}{ Reading Score } \\
\hline$Q_{i}$ & $\begin{array}{l}0.898 \\
(0.42)\end{array}$ & 4.14 & - & - \\
\hline$Q_{j}$ & $\begin{array}{c}-0.641 \\
(0.30)\end{array}$ & -2.49 & - & - \\
\hline$Q_{i} / Q_{j}$ & $\begin{array}{l}-2.696 \\
(-0.53)\end{array}$ & -3.65 & - & - \\
\hline \multicolumn{5}{|c|}{$\%$ Black Pupils } \\
\hline$R_{i}$ & $\begin{array}{c}0.838 \\
(0.11)\end{array}$ & 2.28 & $\begin{array}{c}0.671 \\
(0.09)\end{array}$ & 2.01 \\
\hline$R_{j}$ & $\begin{array}{l}-0.341 \\
(-0.05)\end{array}$ & -1.13 & $\begin{array}{l}-0.492 \\
(-0.07)\end{array}$ & -1.63 \\
\hline$R_{i} / R_{j}$ & $\begin{array}{l}-0.249 \\
(-0.15)\end{array}$ & -2.44 & $\begin{array}{l}-0.258 \\
(-0.15)\end{array}$ & -2.76 \\
\hline \multicolumn{5}{|c|}{ Neighborhood Income } \\
\hline$Y_{i}$ & $\begin{array}{c}0.144 \\
(0.47)\end{array}$ & 7.70 & $\begin{array}{l}0.156 \\
(0.51)\end{array}$ & 8.63 \\
\hline$Y_{j}$ & $\begin{array}{l}-0.060 \\
(-0.19)\end{array}$ & -3.64 & $\begin{array}{c}-0.051 \\
(-0.17)\end{array}$ & -3.62 \\
\hline$Y / Y_{j}$ & $\begin{array}{l}-1.153 \\
(-0.51)\end{array}$ & -6.44 & $\begin{array}{l}-1.166 \\
(-0.51)\end{array}$ & -6.53 \\
\hline \multicolumn{5}{|c|}{$\%$ Black in Neighborhood } \\
\hline$B_{i}$ & $\begin{array}{c}-0.003 \\
(-0.07)\end{array}$ & -2.98 & $\begin{array}{l}-0.003 \\
(-0.07)\end{array}$ & -2.86 \\
\hline$B_{j}$ & $\begin{array}{c}-0.001 \\
(-0.02)\end{array}$ & -0.83 & $\begin{array}{l}-0.001 \\
(-0.02)\end{array}$ & -0.75 \\
\hline$B_{i} / B_{j}$ & $\begin{array}{c}-0.000 \\
(-0.00)\end{array}$ & -0.09 & $\begin{array}{l}-0.000 \\
(-0.01)\end{array}$ & -0.24 \\
\hline \multicolumn{5}{|l|}{ Distance } \\
\hline$D_{i}$ & $\begin{array}{c}0.471 \\
(0.60)\end{array}$ & 3.79 & $\begin{array}{c}0.308 \\
(0.39)\end{array}$ & 2.55 \\
\hline$D_{j}$ & $\begin{array}{c}-0.426 \\
(-0.54)\end{array}$ & -3.45 & $\begin{array}{l}-0.284 \\
(-0.36)\end{array}$ & -2.35 \\
\hline$D_{i} / D_{j}$ & $\begin{array}{l}-5.490 \\
(-0.82)\end{array}$ & -3.74 & $\begin{array}{c}-3.60 \\
(-0.54)\end{array}$ & -2.53 \\
\hline \multicolumn{5}{|l|}{ Age } \\
\hline$A_{i}$ & $\begin{array}{l}0.003 \\
(0.04)\end{array}$ & 1.00 & $\begin{array}{c}0.005 \\
(0.07)\end{array}$ & 1.57 \\
\hline$A_{j}$ & $\begin{array}{l}0.018 \\
(0.24)\end{array}$ & 5.40 & $\begin{array}{c}0.014 \\
(0.19)\end{array}$ & 4.39 \\
\hline$A_{i} / A_{j}$ & $\begin{array}{c}0.066 \\
(0.08)\end{array}$ & 1.82 & $\begin{array}{c}0.031 \\
(0.04)\end{array}$ & 0.88 \\
\hline \multicolumn{5}{|c|}{ Population } \\
\hline$P_{i}$ & $\begin{array}{l}-0.003 \\
(-0.01)\end{array}$ & -0.68 & $\begin{array}{l}-0.002 \\
(-0.01)\end{array}$ & -0.55 \\
\hline$P_{j}$ & $\begin{array}{l}-0.006 \\
(-0.04)\end{array}$ & -1.60 & $\begin{array}{l}-0.003 \\
(-0.02)\end{array}$ & -0.89 \\
\hline $\mathrm{R}^{2}$ & 0.09 & & 0.08 & \\
\hline
\end{tabular}

the housing market in Charlotte functioned such that housing consumers were able to move to neighborhoods with good schools and other desirable amenities.

As with most economic arguments, it is possible to question the direction of causation. That is, one might want to argue that inmigration results in better schools rather than the reverse. We believe the nature of the data used to estimate equation [1] are sufficient to substantially eliminate the possibility of this type of simultaneous equation bias. First, the number of in-migrants from any one neighborhood into any other neighborhood is so small that it seems exceedingly unlikely that in-migrants could meaningfully have affected average achievement scores. Second, the state achievement tests in North Carolina are administered in the spring of the year, prior to the summer when residential real estate sales are highest and most household moves are made.

The coefficients on the school racial variables $\left(R_{i}\right.$ and $\left.R_{j}\right)$ do not have the expected signs. Neighborhood choice does not seem to be negatively affected by the racial composition of the school attendance area once other neighborhood factors are held constant. Again, these findings are consistent with those of Jud and Watts.

The overall model appears relatively robust with regard to specification. Elimination of the school quality variables significantly reduces the explanatory power of the equation but results in few noteworthy changes in the magnitudes of the coefficients of other variables. The size of the income and distance coefficients change somewhat as do their $t$-values, but the differences are not great.

In Table 1, the standardized regression (or beta) coefficients are listed in parentheses below the unstandardized coefficients. The standardized coefficients provide a useful means of interpreting the relative effects of independent variables within the same regression equation. The dependent variable is most responsive to those independent variables whose beta coefficients have the largest absolute values. Looking at the non-ratio variables in Table 1, the distance variables have the highest beta values followed by elementary reading score and neighborhood income. 
The coefficients on the neighborhood income and race variables in Table 1 suggest that, other things being equal, urban movers are likely to move to neighborhoods where the quality of housing and other amenities is high and the percentage of black residents is low. The coefficient of $B_{i j}$ is negative, suggesting that movers are less likely to move from black neighborhoods. This coefficient is not statistically significant, however. The negative sign probably reflects the fact that fewer residents of predominantly black neighborhoods purchase homes anywhere in the city.

The distance variables show that movers prefer neighborhoods farther from the employment center of the SMSA. Urban economic theory suggests that households balance commuting costs against the price of land and housing when choosing a place to live. The evidence here indicates that for most movers in Charlotte during this period relative costs favored a more distant location.

The age variables indicate that neighborhood out-migration rises with the age of the housing stock but that in-migration is not significantly influenced by age when other variables are held constant.

The population variables are not statistically significant in Table 1. It is likely that this stems from the limited variation of neighborhood population within school assignment zones.

\section{SCHOOL ENROLLMENT CHANGES IN LOS ANGELES}

Data on school enrollment changes in the Los Angeles County school districts between 1977 and 1979 offer further evidence of the relationship between public schools and residential location. Using data obtained from the California Assessment Program for 55 independent school districts in Los Angeles County, equation [3] was estimated as the net migration rate of white pupils in Los Angeles County school districts. The estimating equation was defined as follows:

$$
\begin{aligned}
N M R_{i}= & a_{0}+b_{1} Q_{i}+b_{2} R_{i}+b_{3} Y_{i}+ \\
& b_{4} D_{i}+b_{5} T_{i}+b_{6} E_{i}+e_{i}
\end{aligned}
$$

where,

$$
\begin{aligned}
N M R_{i}= & \text { the net migration rate of white pu- } \\
& \text { pils in school district } i \text { during } \\
& 1977-79 . \text { This rate was calculated } \\
& \text { by dividing the change in the num- } \\
& \text { ber of the white pupils by the total } \\
& \text { white enrollment in } 1977 ; \\
T_{i}= & \text { the effective property tax rate in } \\
& \text { district } i \\
E_{i}= & \text { a dummy variable equal to one } \\
& \text { (zero otherwise) if the school dis- } \\
& \text { trict included only elementary } \\
& \text { grades, and; }
\end{aligned}
$$

$Q_{i}, R_{i}, Y_{i}, D_{i}$, and $e_{i}$ are as previously defined.

Since there is no inter-district busing in Los Angeles County, the racial composition of the district schools $\left(R_{i}\right)$ reflects the racial makeup of the communities served by the schools, except for differences resulting from racial variations among population cohorts and private school enrollments. Because of this, the racial composition of the school district was not separated from that of the community at large in equation [5] as it was in equation [4]. Accordingly, the estimated coefficients on the racial variable in [5] reflect both school and community effects.

Estimates of equation [5] are shown in Table 2. Again, as in Table 1, test scores as a proxy for the quality of public schools appear as a strong determinant of intraurban migration. The coefficient on the property tax variable is negative, as might be expected, but not statistically significant. The other results shown in Table 2 are consistent with the findings for Charlotte reported in Table 1, except for the income variable which is insignificant and has an unexpected negative sign.

Table 2 shows that in Los Angeles as in Charlotte the racial composition of the public schools is not a significant influence on migration rates, once account has been taken of educational quality. However, if the school quality variable is not included in the net migration equation (see column (II) in Table 2), the racial make-up of the school district has a more negative and statistically stronger effect. In this case also the income variable appears statistically significant with a positive coefficient. These results are evidence that the fail- 
TABLE 2

Net-Migration of White School Children in Los Angeles Schools, 1977-79 $(\mathrm{N}=55)$

\begin{tabular}{|c|c|c|c|c|}
\hline \multirow[b]{2}{*}{ Variable } & \multicolumn{2}{|c|}{ (I) } & \multicolumn{2}{|c|}{ (II) } \\
\hline & $\begin{array}{l}\text { Coefficient } \\
\text { (Beta) }\end{array}$ & t-value & $\begin{array}{l}\text { Coefficient } \\
\text { (Beta) }\end{array}$ & $\mathrm{t}$-value \\
\hline Constant & -0.5658 & 5.44 & -0.3082 & -3.80 \\
\hline Reading Score $\left(Q_{i}\right)$ & $\begin{array}{c}0.0014 \\
(0.594)\end{array}$ & 3.46 & - & - \\
\hline$\%$ Black Pupils $\left(\mathrm{R}_{\mathrm{i}}\right)$ & $\begin{array}{l}-0.0009 \\
(-0.139)\end{array}$ & -1.19 & $\begin{array}{l}-0.0017 \\
(-0.272)\end{array}$ & -2.20 \\
\hline Income $\left(Y_{i}\right)$ & $\begin{array}{l}-0.0008 \\
(-0.088)\end{array}$ & -0.54 & $\begin{array}{c}0.0029 \\
(0.333)\end{array}$ & 2.75 \\
\hline Distance $\left(D_{i}\right)$ & $\begin{array}{c}0.0040 \\
(0.346)\end{array}$ & 3.32 & $\begin{array}{c}0.0046 \\
(0.403)\end{array}$ & 3.51 \\
\hline Tax Rate $\left(\mathrm{T}_{i}\right)$ & $\begin{array}{l}-0.0022 \\
(-0.023)\end{array}$ & -0.13 & $\begin{array}{l}-0.0086 \\
(-0.093)\end{array}$ & -0.49 \\
\hline Elementary $\left(E_{i}\right)$ & $\begin{array}{c}-0.0269 \\
(-0.139)\end{array}$ & -0.83 & $\begin{array}{r}-0.0363 \\
(-0.187)\end{array}$ & -1.00 \\
\hline $\mathrm{R}^{2}$ & 0.55 & & 0.43 & \\
\hline
\end{tabular}

ure to properly consider the quality of local public schools may impart a significant bias to the school racial variable, making student racial composition appear much stronger and more significant than it may actually be. Also, some of the influence normally attributed to the income variable in other studies may reflect the better quality of public education in higher income areas.

The standardized regression coefficients shown in Table 2 further attest to the influence of school quality in the Los Angeles case. The school quality variable has the highest beta value among variables in the estimated equation, nearly twice as large as that of the distance variable which has the second largest beta coefficient.

\section{CONCLUSION}

This paper has estimated a model of intraurban neighborhood choice using data from the Charlotte and Los Angeles areas. Estimates of this model revealed that the quality of public education, independent of school racial composition, was important in shaping the pattern of intraurban population change. In addition, the Los Angeles estimates show that the failure to control for school quality in a model of intraurban migration may impart a significant bias to any estimate of the effect of school racial composition and neighborhood income.

In the policy realm, the results of this study suggest that programs to upgrade the quality of urban public schools may be important in stemming the flight of families out of urban areas. In both the Charlotte and Los Angeles cases, the influence of school quality appears to be sufficiently independent of race to offer the hope that by creating better urban public schools cities can once again become attractive places for all families to live.

\section{References}

Armor, David J. 1980. "White Flight and the Future of School Desegregation." In School Desegregation, eds. Walter G. Stephan and Joe R. Feagin. New York: Plenum Press.

Armor, David J., Gerald Sumner, and Velma M. Thompson. 1976. Analysis of the School Preferred Reading Program in Selected Los Angeles Minority Schools. Santa Monica, Calif.: Rand Corporation, R-2007-LAUSD.

Bennett, D. Gordon, and Ole Gade. 1979. Geographic Prospectives in Migration Research: A Bibliographic Survey. Chapel Hill, N.C.: Department of Geography, University of North Carolina at Chapel Hill.

Brown, Alan A., and Egon Neuberger. 1977. Internal Migration: A Comparative Perspective. New York: Academic Press. 
Brown, Larry A., and Eric Moore. 1970. "The Intra-Urban Migration Process: A Perspective." Geografiska Annaler 52B:1-13.

Chang, David. 1983. "The Bus Stops Here." Boston University Law Review 69 (1): 2-58.

Christian Science Monitor. 1982. "Magnet Schools in New Jersey." Christian Science Monitor February 5: 315.

Clotfelter, Charles. 1979. "Urban School Desegregation and Declines in White Enrollment: A Reexamination." Journal of Urban Economics 6 (July): $352-70$.

Coleman, James S., Ernest Q. Campbell, Carol J. Hobson, James McPartland, Alexander M. Mood, Frederic D. Weinfield, and Robert L. York. 1966. Equality of Educational Opportunity, two volumes, Washington: U. S. Government Printing Office.

Coleman, James S., Sara Kelly, and John Moore. 1975. "Recent Trends in School Integration 1968-73." Washington, D. C.: Urban Institute Paper, 722-03-01 (April).

de Castro Lopo, Lisbet A. 1975. Theory of Internal Migration: A Review. Newcastle, New South Wales, Australia: Research Papers in Geography, Vol. 5.

Farley, Reynolds, and Clarence Wurdock. 1977. "Can Government Policies Integrate Public Schools?" Ann Arbor: Population Studies Center, University of Michigan.

Gallup, George H. 1983. "The 15th Annual Gallup Poll of the Public's Attitudes Toward the Public Schools." Phi Delta Kappan 65 (Sept.): 33-47.

Greenwood, Michael J. 1975. "Research on Internal Migration in the United States: A Survey." Journal of Economic Literature 13 (June): 397 433.

Hagerstrand, Torsten. 1962. "Geographical Measurements of Migration." In Human Displacements, ed. Jean Sutter. Monaco: Entreaties de Monaco en Sciences Humaines.

Harris, Louis. 1976. "The Issue: Quality of Life." The Harris Survey (Nov. 8).

Harrison, David and Daniel L. Rubinfeld. 1978. "Hedonic Housing Prices and the Demand for Clean Air." Journal of Environmental Economics and Management 5 (Mar.): 81-102.
Hoyt, Homer. 1939. The Structure and Growth of Residential Neighborhoods in American Cities. Washington, D. C.: Federal Housing Administration.

Jud, G. Donald. 1985. "Public Schools and Urban Development," American Planning Association Journal 51 (Winter): 74-83.

Jud, G. Donald, and James M. Watts. 1981. "Schools and Housing Values." Land Economics 57 (Aug.): 459-70.

Levine, David U., and Joyce Stark. 1982. "Instructional and Organizational Arrangements that Improve Achievement in Inner City Schools." Educational Leadership 40 (Dec.): 41-46.

Li, Mingche M., and H. James Brown. 1980. "Micro-Neighborhood Externalities and Hedonic Housing Prices." Land Economics 56 (May): 125-41.

Purkey, Stewart C., and Marshall S. Smith. 1982. "Synthesis of Research on Effective Schools." Educational Leadership 40 (Dec.): 64-69.

Rossell, Christine H. 1978a. "School Desegregation and Resegregation." Durham, N. C.: Institute of Policy Sciences, Duke University. 1978b. "White Flight: Pros and Cons." Social Policy 9,3: 46-51.

Rossi, Peter H. 1955. Why Families Move. Glencoe, Ill.: The Free Press.

Rutter, Michael, et al. 1979. Fifteen Thousand Hours: Secondary Schools and Their Effects on Children. Cambridge: Harvard University Press.

Tiebout, Charles M. 1956. "A Pure Theory of Local Expenditures," Journal of Political Economy 64 (Oct.): 416-24.

Vandell, Kerry D., and Robert H. Zerbst. 1984. "School Desegregation and Housing Values: An Application of Ridge Regression." AREUEA Journal 12 (Summer): 109-35.

Williams, Dennis A. 1981. "The Bright Flight." Newsweek. April 20: 66-73.

Willis, K. G. 1974. Problems of Migration Analysis. London: Saxon House.

Wolpert, Julian. 1965. "Behavioral Aspects of the Decision to Migrate." Regional Science Association Papers and Proceedings 15:159-169. 
Copyright of Land Economics is the property of University of Wisconsin Press and its content may not be copied or emailed to multiple sites or posted to a listserv without the copyright holder's express written permission. However, users may print, download, or email articles for individual use. 